\title{
ANTIMICROBIAL ACTIVITIES OF DITERPENOIDS AND SEMISYNTHETIC DERIVATIVES FROM AZORELLA COMPACTA
}

\author{
S. NÚÑEZ $I^{*}$, A. SAN-MARTÍN² AND G. CORSINI ${ }^{3}$

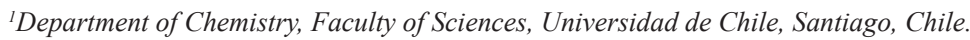 \\ ${ }^{2}$ Faculty of Sciences, Universidad de Magallanes, Punta Arenas, Chile. \\ ${ }^{3}$ Biomedical Reseach Center, Universidad Autónoma de Chile, Santiago, Chile. \\ Contacto/Contact: Solange Núñez, Graduate School, Faculty of Sciences, Universidad de Chile, Santiago, Chile.
}

\begin{abstract}
The antibacterial activity of two natural diterpenoids isolated from Azorella compacta together with six semisynthetic derivatives, were evaluated against three bacteria: Staphylococcus aureus, Escherichia coli and Mycobacterium smegmatis. The synthesis of the semisynthetic derivatives 3-5 and 8 have not been previously reported with the methods described in this research. The structures of all diterpenoids were elucidated by NMR ${ }^{1} \mathrm{H}$, ${ }^{13} \mathrm{C}$ and $\mathrm{IR}$ spectroscopy. The natural diterpenoids, mulinolic ácid (1) and azorellanol (2) did not present antibacterial activity, but the six derivatives: 12-oxo-11,13- $\alpha, \alpha$-dihydroxymulin-20-oic ácid (3), 11-oxo-12,13- $\alpha, \alpha$-dihydroxymulin-20-oic ácid (4) 11,12-dioxo-13- $\alpha$-hydroxymulin-20-oic ácid (5), 7-acetoxymulin-9,12-diene (6), mulin-9,12-dien-7-ol (7) and 7-acetoxy-12,13-dihydroxymulin-9-en (8) were active against three tested bacteria. The antibacterial activity reported for six semisynthetic diterpenoids may not be comparable with positive control ampicillin but demonstrate the possibility of modification of the biological activity of diterpenoids.
\end{abstract}

Keywords: Azorella compacta, Apiaceae, diterpenoids, antibacterial activity

\section{INTRODUCTION}

Azorella compacta, commonly known as llareta or yareta, belongs to Apiaceae family and is a greenish yellow shrub which grows like a dense cushion, hard and resinous ${ }^{1-3}$. It grows exclusively in rocky slopes between 3800 and 5200 m.a.s.l. in the Andean zone of Chile, Argentina, Perú and Bolivia $^{4}$. Llareta has been consumed as an infusion to relieve symptoms of altitude sickness, purify the blood, against digestive problems and fight diabetes. Also its resin is used topically to relieve inflammation ${ }^{1}$.

From the Apiaceae family have been determined the presence of flavonoids ${ }^{5}$, polyacetylenes $^{6}$, sesquiterpenes ${ }^{7}$ and coumarins $^{8}$, with anti-inflammatory, anticarcinogenic, antibacterial, antifungal and antioxidant activity ${ }^{9-12}$. While, from Azorella compacta has been separated and purified diterpenoids with mulinane and azorellane skeletons, which in addition to studying their biological activities, have been modified through biotransformations ${ }^{13-14}$ and chemical reactions like dehydrations, hydroxylations, sterifications, among others $^{15-16}$.

Natural and semisynthetic diterpenoids showed antiparasitic activity on Trypanosoma cruzi $^{17}$, hypoglycemic ${ }^{18}$, anti-inflammatory ${ }^{19}$, antibacterial against Mycobacterium tuberculosis ${ }^{20}$, antioxidant ${ }^{21}$ and considerable gastroprotective activity ${ }^{22}$.

To continue with this research about the new potentials of Azorella compacta is has been studied antibacterial activity against $S$. aureus, E. coli and M. smegmatis, and the possibility of increasing the biological activity of diterpenoids through chemical transformations on their structures.

\section{MATERIAL AND METHODS}

\section{Chemical Material}

Thin-layer chromatography (TLC) was made on silica gel $60 \mathrm{GF}_{254}$ (Merck) and were eluted with $n$-hexane/EtOAc mixtures $(1: 9$ to $2: 3 \mathrm{v} / \mathrm{v})$, to be visualized later under UV light $(254 \mathrm{~nm})$. Then, the spots were revealed by spraying with $\mathrm{H}_{2} \mathrm{SO}_{4} / \mathrm{MeOH} 10 \%$ and heating at $100^{\circ} \mathrm{C}$. Silica gel $60 \mathrm{G}$ particle size 10 - $15 \mu \mathrm{m}$ (Merck) and P60 particle size 40 - $63 \mu \mathrm{m}$ (Merck) were used to column chromatography, and eluted with $n$-hexane/EtOAc in gradient.

Instrumentation

Isolera $^{\text {TM }}$ Spektra Biotage HPLC was used to purify compounds with HPsphere $25 \mu \mathrm{m}$ of 10 and 25 grams columns. ${ }^{1} \mathrm{H}$ - NMR spectra were registered dissolving compounds in $\mathrm{CDCl}_{3}$ at $400.13 \mathrm{MHz}$, while ${ }^{13} \mathrm{C}$-NMR spectra were registered at $125.03 \mathrm{MHz}$ in a Bruker Avance AM-400 multidimensional spectrometer. The displacement values were expressed using TMS as interna standard. IR spectra were recorded on a FT-IR Thermo Nicolet Nexus 670 (resolution $0.125 \mathrm{~cm}^{-1}$ ) spectrometer with $\mathrm{KBr}$ plates and frequencies between 500 to $4000 \mathrm{~cm}^{-1}$.

Plant material

Azorella compacta Phil. Apiaceae was collected in May 2013 at Tatio (4200 m.a.s.1.), II Region Antofagasta Chile. A sample specimen was deposited at the Herbarium of Natural Products Laboratory of Faculty of Science, Universidad de Chile, under de code $n^{\circ} 0513$.

Extraction and isolation

The isolation of diterpenoids mulinolic acid (1) and azorellanol (2), was carried out from the aerial parts of Azorella compacta, which were dried and extracted with $n$-hexane. The extract was filtered and dried under reduced pressure obtaining a concentrated $(95 \mathrm{~g})$ which was impregnated in silica gel to subject it to a flash column chromatography (silica gel $60 \mathrm{G}$ particle size 10 - $15 \mu \mathrm{m}$ ) eluted with a mixture of $n$-hexane/EtOAc increasing polarity (1:0 to $0: 1 \mathrm{v} / \mathrm{v})$. Subsequently, the fractions obtained were again subjected to various column chromatographies at normal pressure (silica gel $60 \mathrm{G}$ particle size 40 $63 \mu \mathrm{m})$, to separate components without interest from the concentrated. The eluent used was a mixture of $n$-hexane/EtOAc in gradient $(0: 1$ to $3: 2 \mathrm{v} / \mathrm{v})$.

Finally, the fractions obtained from the column chromatographies were compared by thin layer chromatography ( $n$-hexane/EtOAc 7:3 v/v as solvent) with standards of compounds $\mathbf{1}$ and $\mathbf{2}$ previously isolated from $A$. compacta. Those that presented the diterpenoids of interest were subjected to Isolera TM Spektra Biotage HPLC chromatography for purification, using a gradient mixture of $n$-hexane/EtOAc as solvent.

Two colorless crystalline solids were obtained from the extracts of Azorella compacta. 1.7 grams of mulinolic acid (1) and 3.9 grams of azorellanol (2).

\section{- $\quad$ Mulinolic acid (1)}

Compound 1: m.p.: $178-180{ }^{\circ} \mathrm{C} ;{ }^{1} \mathrm{H}-\mathrm{NMR} \delta(\mathrm{ppm}): 0.86(\mathrm{~d}, J=5.8 \mathrm{~Hz}, 3 \mathrm{H}$, H-18); 0.94 (s, 3H, H-17); 1.04 (d, $J=5.8$ Hz, 3H, H-19); 1.32 (s, 3H, H-16); $5.23(\mathrm{dd}, J=8.2$ y $12.9 \mathrm{~Hz}, 1 \mathrm{H}, \mathrm{H}-11)$ y 5.44 (d, $J=12.9 \mathrm{~Hz}, 1 \mathrm{H}, \mathrm{H}-12)$. Azorellanol (2)

Compound 2: m.p.: $149^{\circ} \mathrm{C}$; ${ }^{1} \mathrm{H}-\mathrm{NMR} \delta(\mathrm{ppm}): 0.13(\mathrm{t}, J=5.6 \mathrm{~Hz}, 1 \mathrm{H}$, $\mathrm{H}-12) ; 0.69$ (ddd, $J=1.11,6.0$ and $9.8 \mathrm{~Hz}, 1 \mathrm{H}, \mathrm{H}-11 \beta) ; 0.78$ (dd, $J=5.6$ and $9.8 \mathrm{~Hz}, 1 \mathrm{H}, \mathrm{H}-11 \alpha) ; 0.91$ (s, 3H, H-20); 2.03 (s, 3H, OAc); 2.20 (dd, $J=7.0$ and $13.8 \mathrm{~Hz}, 1 \mathrm{H}, \mathrm{H}-6 \alpha) ; 2.40(\mathrm{dd}, J=7.1$ and $12.4 \mathrm{~Hz}, 1 \mathrm{H}, \mathrm{H}-10)$ and $5.28(\mathrm{dd}$, $J=7.0$ and $11.4 \mathrm{~Hz} 1 \mathrm{H}, \mathrm{H}-7)$.

\section{Preparation of diterpenoid derivates}

Oxidation of mulinolic acid (1)

$300 \mathrm{mg}$ of mulinolic acid (1) were dissolved in $20 \mathrm{~mL}$ of acetone and $400 \mathrm{mg}$ of $\mathrm{KMnO}_{4}$ in $5 \mathrm{~mL}$ of water were added together with $5 \mathrm{~mL}$ of acetic acid $90 \%$. The reaction was monitored by TLC ( $n$-hexane/EtOAc $7: 3 \mathrm{v} / \mathrm{v}$ ) and manteined with magnetic stirring at room temperature Once the reaction was completed, it was neutralized with a saturated solution of $\mathrm{NaHCO}_{3}$ and the solvent was concentrated to dryness. Then the products were extracted with four $20 \mathrm{~mL}$ portions of DCM, in a separatory funnel. The mixture of products was separated in a preparative HPLC, with a gradient mixture of $n$-hexane/EtOAc as solvent. 
$56 \mathrm{mg}$ of compound 3 (colorless solid, 17\%), $47 \mathrm{mg}$ of compound 4 (colorless solid, 14\%) and $36 \mathrm{mg}$ of compound 5 (white solid, 11\%), were obtained.

12-oxo-11,13- $\alpha, \alpha$-dihydroxymulin-20-oic acid (3)

Compound 3 m.p.: $164-165^{\circ} \mathrm{C}$; IR $\left(\mathrm{cm}^{-1}\right): 3.420,1.704$ and $1.693 ;{ }^{1} \mathrm{H}-\mathrm{NMR}$ $\delta(\mathrm{ppm}): 1.46(\mathrm{~s}, 3 \mathrm{H}, \mathrm{H}-16) ; 1.94(\mathrm{da}, J=12.0 \mathrm{~Hz}, 1 \mathrm{H}, \mathrm{H}-9) ; 2.26(\mathrm{dd}, J=3.2$ and $12.0 \mathrm{~Hz}, 1 \mathrm{H}, \mathrm{H}-10)$ and 4.67 (da, $J=0.9 \mathrm{~Hz}, 1 \mathrm{H}, \mathrm{H}-11) .{ }^{13} \mathrm{C}-\mathrm{NMR} \delta$ (ppm): 22.34 (c); 22.70 (c); 25.14 (c); 26.47 (c); 27.44 (t); 28.51 (d); 29.76 (t); $31.76(\mathrm{t}) ; 32.30(\mathrm{t}) ; 34.94(\mathrm{t}) ; 37.30(\mathrm{t}) ; 43.88(\mathrm{~s}) ; 48.60(\mathrm{~d}) ; 51.50(\mathrm{~d}) ; 57.89$ (d); 58.65 (s); 77.71 (d, C-11); 79.07 (s, C-13); 178.83 (s, C-20) and 215.36 (s, C-12).

11-oxo-12,13- $\alpha, \alpha$-dihydroxymulin-20-oic acid (4)

Compound 4 m.p.: $157-158^{\circ} \mathrm{C}$; IR $\left(\mathrm{cm}^{-1}\right): 3.425,1.707$ and $1.695 ;{ }^{1} \mathrm{H}-\mathrm{NMR}$ $\delta$ (ppm): 1.14 (s, 3H, H-16); 2.33 (m, 1H, H-10); 2.50 (d, $J=12.3 \mathrm{~Hz}, 1 \mathrm{H}, \mathrm{H}-9)$ and $4.46(\mathrm{~s}, 1 \mathrm{H}, \mathrm{H}-12) .{ }^{13} \mathrm{C}-\mathrm{NMR} \delta(\mathrm{ppm}): 22.17$ (c); 22.55 (c); 24.01 (c); 25.87 (c); $27.16(\mathrm{t}) ; 28.64(\mathrm{~d}) ; 29.93(\mathrm{t}) ; 30.54(\mathrm{t}) ; 33.41(\mathrm{t}) ; 35.48(\mathrm{t}) ; 36.31(\mathrm{t}) ; 43.58$ (s); 48.02 (d); 54.97 (d); 56.62 (d); 59.11 (s); 77.61 (s, C-13); 84.08 (d, C-12); 179.41 (s, C-20) and 212.54 (s, C-11)

11,12-dioxo-13- $\alpha$-hydroxymulin-20-oic acid (5)

Compound 5 m.p.: $173-175^{\circ} \mathrm{C}$; IR $\left(\mathrm{cm}^{-1}\right): 3.445,1.720$ and $1.706 ;{ }^{1} \mathrm{H}-\mathrm{NMR}$ $\delta(\mathrm{ppm}): 1.36(\mathrm{~s}, 3 \mathrm{H}, \mathrm{H}-16) ; 2.29(\mathrm{~m}, 1 \mathrm{H}, \mathrm{H}-10)$ and $2.57(\mathrm{~d}, J=11.5 \mathrm{~Hz}, 1 \mathrm{H}$, H-9). ${ }^{13}$ C-NMR $\delta(\mathrm{ppm}): 22.43$ (c); 22.66 (c); $24.06(\mathrm{c}) ; 27.38(\mathrm{c}) ; 27.80(\mathrm{t}) ;$ $28.22(\mathrm{~d}) ; 30.79(\mathrm{t}) ; 31.50(\mathrm{t}) ; 31.75(\mathrm{t}) ; 32.03(\mathrm{t}) ; 35.77(\mathrm{t}) ; 40.82(\mathrm{~s}) ; 46.19$ (d); $56.80(\mathrm{~d}) ; 57.26(\mathrm{~d}) ; 59.69$ (s); $75.11(\mathrm{~s}, \mathrm{C}-13) ; 178.31$ (s, C-20); 209.20 (s, $\mathrm{C}-11)$ and 211.23 (s, C-12)

\section{Dehydration of azorellanol}

$50 \mathrm{mg}$ of azorellanol (2) were dissolved in $50 \mathrm{~mL}$ of $\mathrm{MeOH}$ and $40 \mathrm{mg}$ of para-toluenesulfonic acid were added. The reaction was maintained under reflux and magnetic stirring for three hours, determining the product formation by TLC ( $n$-hexane/EtOAc 7: $3 \mathrm{v} / \mathrm{v})$. To finish the reaction, the solution was neutralized with $\mathrm{NaHCO}_{3}$ and the $\mathrm{MeOH}$ was evaporated under reduced pressure. The product was extracted with three $20 \mathrm{~mL}$ portions of DCM in a separatory funnel, dried with anhydrous $\mathrm{Na}_{2} \mathrm{SO}_{4}$ and the solvent was evaporated in vacuo. Compound $\mathbf{6}$ was separated by preparative HPLC, with a gradient mixture of $n$-hexane/EtOAc. $39 \mathrm{mg}$ of colorless oil were obtained with a yield of $84 \%$.

7-acetoxymulin-9,12-diene (6)

Compound 6 IR $\left(\mathrm{cm}^{-1}\right): 1.732 ;{ }^{1} \mathrm{H}-\mathrm{RMN} \delta(\mathrm{ppm}): 1.59$ (s, 3H, H-16); 2.05 (s, 3H, OAc); 2.22 (dd, $J=5.6$ and $13.8 \mathrm{~Hz}, 1 \mathrm{H}, \mathrm{H}-6 \alpha$ ); 2.47 (dd, $J=8.2$ and $16.1 \mathrm{~Hz}, 1 \mathrm{H}, \mathrm{H}-11) ; 2.74$ (da, $J=16.2 \mathrm{~Hz}, 1 \mathrm{H}, \mathrm{H}-11) ; 4.96$ (dd, $J=5.6$ and 10.5 $\mathrm{Hz}, 1 \mathrm{H}, \mathrm{H}-7)$ and 5.41 (da, $J=8.2,1 \mathrm{H}, \mathrm{H}-12) .{ }^{13} \mathrm{C}-\mathrm{NMR} \delta(\mathrm{ppm}): 21.25(\mathrm{c})$; $21.36(\mathrm{c}) ; 22.44(\mathrm{~d}) .22 .86(\mathrm{c}) ; 22.97(\mathrm{c}) ; 25.44(\mathrm{t}) ; 25.63(\mathrm{c}) ; 27.28(\mathrm{t}) ; 27.63$ (t); $30.01(\mathrm{t}) ; 30.87(\mathrm{~d}) ; 34.39(\mathrm{t}) ; 35.34(\mathrm{t}) ; 41.04(\mathrm{~s}) ; 43.06(\mathrm{~s}) ; 54.51(\mathrm{~d})$; 72.66 (d, C-7); 121.41 (d, C-12); 131.85 (s, C-10); 136.62 (s, C-13); 142.03 (s, C-9) and 170.73 (s, OAc)

\section{Hydrolysis of 7-acetoxymulin-9,12-diene}

$50 \mathrm{mg}$ of 7-acetoxymulin-9,12-diene (6) were dissolved in $20 \mathrm{~mL}$ of $\mathrm{MeOH}$ and then $60 \mathrm{mg}$ of $\mathrm{K}_{2} \mathrm{CO}_{3}$ were added. The reaction was maintained under reflux and with magnetic stirring for two hours, following the course of the reaction by TLC $(n$-hexane/EtOAc 9: $1 \mathrm{v} / \mathrm{v})$. Once the reaction time had elapsed, it was neutralized and separated in a decantation funnel with three $20 \mathrm{~mL}$ portions of DCM. The product obtained was purified on preparative HPLC, with a gradient mixture of $n$-hexane/EtOAc, $38 \mathrm{mg}$ of colorless solid corresponding to compound 7 being isolated ( $87 \%$ yield).

Mulin-9,12-dien-7-ol (7)

Compound 7 m.p.: $141{ }^{\circ} \mathrm{C}$; IR $\left(\mathrm{cm}^{-1}\right): 3.408 ;{ }^{1} \mathrm{H}-\mathrm{NMR} \delta(\mathrm{ppm}): 1.49(\mathrm{dd}, J$ $=11.4$ and $13.5 \mathrm{~Hz}, 1 \mathrm{H}, \mathrm{H}-6 \beta) ; 1.58(\mathrm{~s}, 3 \mathrm{H}, \mathrm{H}-16) ; 2.29(\mathrm{dd}, J=5.8$ and 13.5 $\mathrm{Hz}, 1 \mathrm{H}, \mathrm{H}-6 \alpha) ; 2.46$ (dd, $J=8.3$ and $16.0 \mathrm{~Hz}, 1 \mathrm{H}, \mathrm{H}-11) ; 2.76(\mathrm{~d}, J=16.0 \mathrm{~Hz}$, $1 \mathrm{H}, \mathrm{H}-11) ; 3.73(\mathrm{dd}, J=5.8 \mathrm{~Hz}$ and $11.4 \mathrm{~Hz}, 1 \mathrm{H}, \mathrm{H}-7)$ and $5.42(\mathrm{da}, J=8.3$ $\mathrm{Hz}, 1 \mathrm{H}, \mathrm{H}-12) .{ }^{13} \mathrm{C}-\mathrm{NMR} \delta$ (ppm): 20.10 (c); 22.48 (c); 23.26 (c); 23.34 (c); $25.46(\mathrm{c}) ; 25.67(\mathrm{t}) ; 27.18(\mathrm{t}) ; 27.64(\mathrm{t}) ; 29.98(\mathrm{~d}) ; 30.94(\mathrm{t}) ; 33.40(\mathrm{t}) ; 39.26$ (s); 42.06 (s); 43.49 (t); 54.30 (d); 69.16 (d, C-7); 121.73 (d, C-12); 132.73 (s, C-10); 136.30 (s, C-13) and 141.84 (s, C-9).

Hydroxymercuration of 7-acetoxymulin-9,12-diene

$50 \mathrm{mg}$ of $\mathrm{Hg}(\mathrm{OAc})_{2}$ were dissolved in $5 \mathrm{~mL}$ of water and $5 \mathrm{~mL}$ of THF. The solution was maintained with magnetic stirring at room temperature. Once the $\mathrm{Hg}(\mathrm{OAc})_{2}$ was dissolved, $50 \mathrm{mg}$ of 7-acetoxymulin-9,12-diene (6) dissolved in THF were added, maintaining the reaction under the same conditions for two days. The reaction was followed by TLC ( $n$-hexane/EtOAc $8: 2 \mathrm{v} / \mathrm{v}$ ), and after the period of 48 hours elapsed $3 \mathrm{mg}$ of $\mathrm{NaBH}_{4}$ dissolved in $2 \mathrm{~mL}$ of 3.0 $\mathrm{M} \mathrm{NaOH}$ was added. The reaction was finished by adding $20 \mathrm{~mL}$ of a saturated $\mathrm{NaCl}$ solution. The mixture was extracted with three $20 \mathrm{~mL}$ portions of DCM. The product was separated by preparative HPLC, with a gradient mixture of $n$-hexane/EtOAc as solvent, obtaining $33 \mathrm{mg}$ of a colorless solid corresponding to compound $\mathbf{8}(60 \%$ yield $)$.

7-acetoxy-12,13-dihydroxymulin-9-en $(\mathbf{8})$

Compound 8 m.p.: $158-160^{\circ} \mathrm{C}$; IR $\left(\mathrm{cm}^{-1}\right): 3.450$ and $1.716 ;{ }^{1} \mathrm{H}-\mathrm{NMR} \delta$ (ppm): 1.17 (s, 3H, H-16); 2.29 (dd, $J=6.3$ and $13.6 \mathrm{~Hz}, 1 \mathrm{H}, \mathrm{H}-6 \alpha$ ) and 4.82 (dd, $J=6.3$ and $11.5 \mathrm{~Hz}, 1 \mathrm{H}, \mathrm{H}-7) .{ }^{13} \mathrm{C}-\mathrm{NMR} \delta(\mathrm{ppm}): 21.38(\mathrm{c}) ; 21.98(\mathrm{c}) ;$ 22.39 (c); 23.08 (c); $23.15(\mathrm{c}) ; 23.33(\mathrm{t}) ; 24.59$ (t); 27.19 (c); $28.70(\mathrm{t}) ; 30.99$ $(\mathrm{d}) ; 32.78(\mathrm{t}) ; 35.58(\mathrm{t}) ; 35.65(\mathrm{t}) ; 40.79(\mathrm{~s}) ; 42.70(\mathrm{~s}) ; 43.14(\mathrm{t}) ; 54.22(\mathrm{~d})$; 70.97 (s, C-13); 72.50 (d, C-7); 132.62 (s, C-10); 144.28 (s, C-9) and 170.84 (s, OAc).

Antibacterial activity in vitro

The antibacterial activity of natural and semisynthetic diterpenoids was carried out by disc diffusion assays, using three bacteria: Staphylococcus aureus, Mycobacterium smegmatis and Escherichia coli.

For the biological assays, the bacteria were cultured in Mueller Hinton broth, prepared with $21.0 \mathrm{~g}$ of medium for 1 liter of deionized and sterilized water. Bacteria were incubated at $37^{\circ} \mathrm{C}$ for 24 hours. Subsequently, the bacteria were deposited on Mueller Hinton agar plates prepared with $18.0 \mathrm{~g}$ of agar and $21.0 \mathrm{~g}$ of medium, for 1 liter of solution, with a $\mathrm{pH}$ of $7 \pm 0.2$ at $25^{\circ} \mathrm{C}$. The agar plates were incubated for 24 hours at $37^{\circ} \mathrm{C}$.

Each product was tested using a concentration of $500 \mu \mathrm{g}$ and the results were expressed through the inhibition zone formed. The initial stock solution of each compound was made by dissolving $10.0 \mathrm{mg}$ of each in $100 \mu \mathrm{L}$ of DCM and impregnating the paper discs with $5 \mu \mathrm{L}$ aliquots.

Subsequently, the determination of the minimum inhibitory concentration (MIC) was carried out by the plate diffusion method using paper squares impregnated with the most active compounds tested, with a final concentration of 50 to $400 \mu \mathrm{g}$.

The assays were performed in triplicate and $1 \mu \mathrm{L}$ of ampicillin was incorporated to each plate at concentration of $1 \mathrm{mg} / \mathrm{mL}$ as a positive control, and discs impregnated only with DCM as target.

\section{RESULTS}

From the chromatographic columns it was possible to isolate two known diterpenes ( 1 and 2, see Figure 1), which were determined by comparison in TLC with previously isolated standards and by ${ }^{1} \mathrm{H}-\mathrm{NMR}$ spectroscopy with data described in the literature ${ }^{23-24}$. From the natural diterpenoids of $A$. compact, six semisynthetic compounds were obtained, modifying the functional groups present in the structures (compounds 3-8, see Figure 1).

The structures of the semi-synthetic compounds were determined by ${ }^{1} \mathrm{H}$, ${ }^{13} \mathrm{C}$ and IR NMR spectroscopy.

For compound 3, two signals displaced at low field were observed in the ${ }^{13} \mathrm{C}$-NMR spectrum, at $\delta=178.83 \mathrm{ppm}$ (s) and $215.36 \mathrm{ppm}$ (s), corresponding to the carbonyl carbons of the carboxylic acid and of the ketone, respectively. Signals were also observed at $\delta=77.71 \mathrm{ppm}(\mathrm{d})$ and $79.07 \mathrm{ppm}$ (s) of the carbons attached to hydroxyl groups. In the ${ }^{1} \mathrm{H}-\mathrm{NMR}$ spectrum, the low-field signal corresponding carbon-11 hydrogen geminal to the hydroxyl group was observed at $\delta=4.67 \mathrm{ppm}(\mathrm{d}, J=0.9 \mathrm{~Hz}, 1 \mathrm{H})$, and the signal from the carbon-16 hydrogen geminal to the $\mathrm{OH}$ group at $\delta=1.46 \mathrm{ppm}(\mathrm{s}, 3 \mathrm{H})$.

In the ${ }^{1} \mathrm{H}-\mathrm{NMR}$ spectrum of compound 4 a signal at $\delta=4.46 \mathrm{ppm}(\mathrm{s}, 1 \mathrm{H})$ was observed corresponding to the carbon-12 hydrogen, another signal at $\delta$ $=2.50 \mathrm{ppm}(\mathrm{d}, J=12.3 \mathrm{~Hz}, 1 \mathrm{H})$, which was assigned to carbon-9 hydrogen and the signal at $\delta=1.14 \mathrm{ppm}(\mathrm{s}, 3 \mathrm{H})$ corresponding to carbon-16 hydrogen, geminal to the $\mathrm{OH}$ group. On the other hand, in the ${ }^{13} \mathrm{C}-\mathrm{NMR}$ spectrum the signals of the carbons attached to the hydroxyl groups were observed at $\delta=$ $84.08 \mathrm{ppm}$ (d) and $77.61 \mathrm{ppm}$ (s), and the signals of the carbonyl carbons at $\delta=$ $179.41 \mathrm{ppm}$ (s), for the carboxylic acid, and $\delta=212.54 \mathrm{ppm}(\mathrm{s})$, for the ketone.

With the multiplicity data of the hydrogen signal of carbon-11 and carbon-12, together with their coupling constants, it was possible to know the location and orientation of the hydroxyl group in carbon-11 of compound 3 , and the carbon-12 of compound 4, managing to differentiate both structures.

Compound 5 was determined by the signals at $\delta=209.20 \mathrm{ppm}(\mathrm{s})$ and $211.23 \mathrm{ppm}(\mathrm{s}) \mathrm{ppm}$, observed in the ${ }^{13} \mathrm{C}$-NMR spectrum, which were assigned to the two ketones formed. In addition, the carbonyl carbon signals of the 
carboxylic acid were observed at $\delta=178.31 \mathrm{ppm}$ (s) and that of the carbon bonded to the hydroxyl group, at $\delta=75.11 \mathrm{ppm}$ (s). This was confirmed in the ${ }^{1} \mathrm{H}-\mathrm{NMR}$ spectrum with the presence of two signals displaced at low field at $\delta$ $=2.29 \mathrm{ppm}(\mathrm{m}, 1 \mathrm{H})$ and $2.57 \mathrm{ppm}(\mathrm{d}, J=11.5 \mathrm{~Hz}, 1 \mathrm{H})$, corresponding to the carbon-10 and carbon-9 hydrogens, respectively. In addition, the signal of the carbon-16 hydrogen geminal at the hydroxyl group was observed at $\delta=1.36$ $\operatorname{ppm}(\mathrm{s}, 3 \mathrm{H})$.
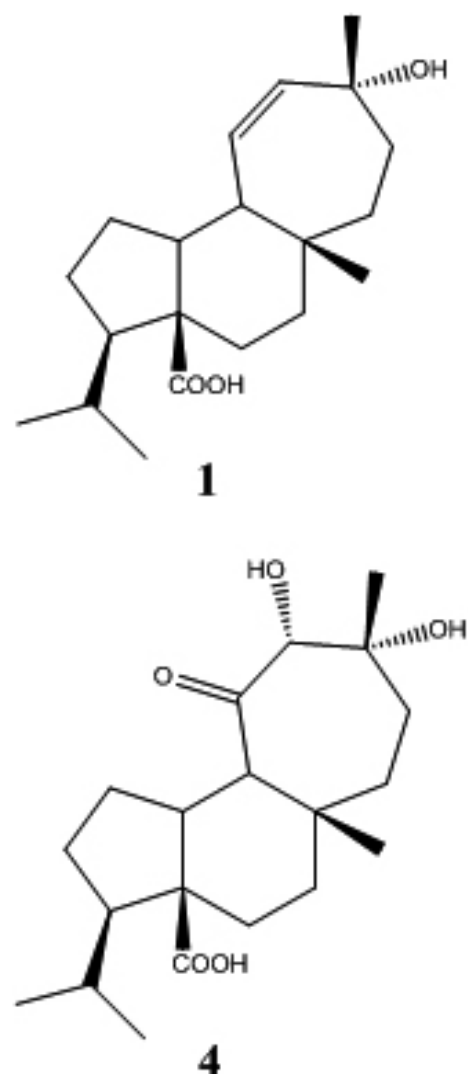

4

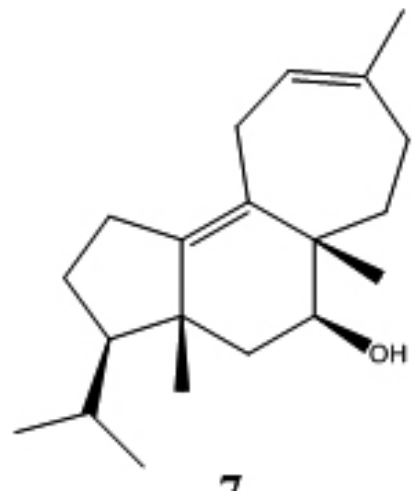

7

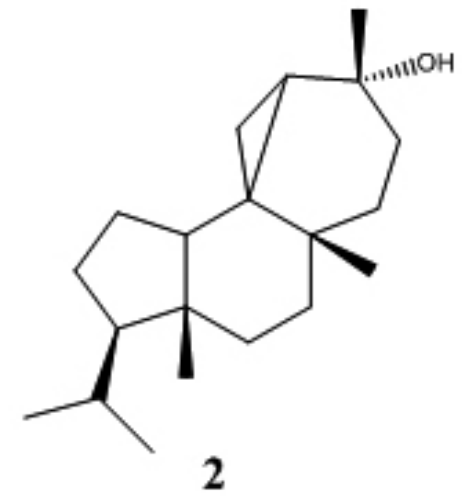

2

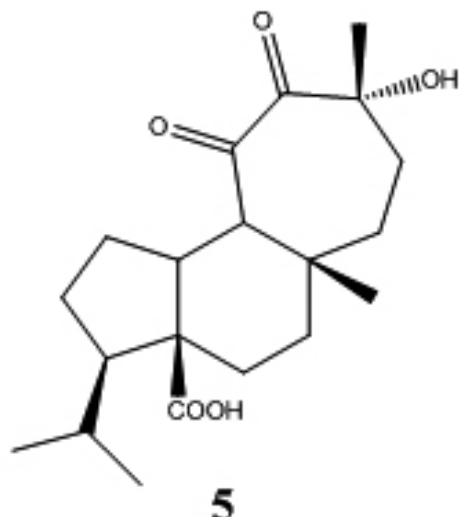

5

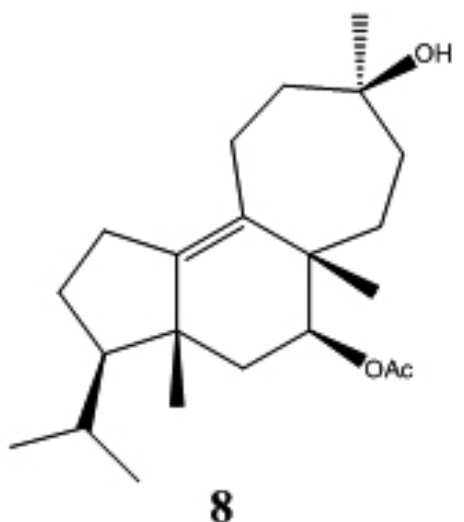

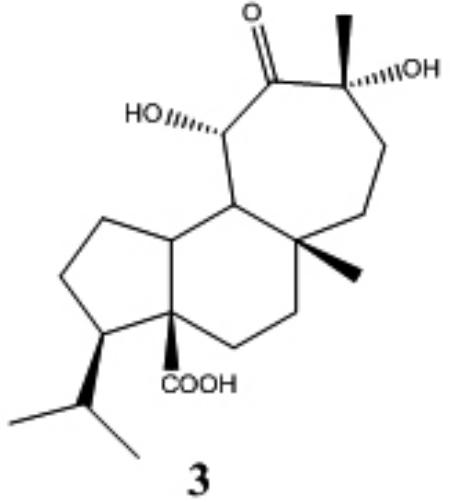

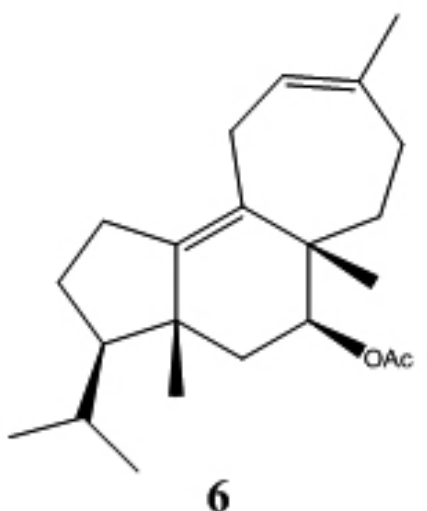

6

Figure 1. Natural and semi-synthetic diterpene structures 1-8. Skeletal numbering of diterpenes 9.

In the ${ }^{1} \mathrm{H}-\mathrm{NMR}$ spectrum of product 6 a vinyl hydrogen at $\delta=5.41 \mathrm{ppm}(\mathrm{d}$, $J=8.2 \mathrm{~Hz}, 1 \mathrm{H})$, the carbon-11 hydrogens at $\delta=2.47 \mathrm{ppm}(\mathrm{dd}, J=8.2$ and 16.2 $\mathrm{Hz}$, and $2.74 \mathrm{ppm}(\mathrm{d}, J=16.2 \mathrm{~Hz})$, indicating the opening of the cyclopropane, and the signal at $\delta=1.59 \mathrm{ppm}(\mathrm{s}, 3 \mathrm{H})$ corresponding to the carbon-16 hydrogens, were observed. In the ${ }^{13} \mathrm{C}$-NMR spectrum the four olefinic carbons were observed at: $\delta=121.41 \mathrm{ppm}(\mathrm{d}), 131.85 \mathrm{ppm}(\mathrm{s}), 136.62 \mathrm{ppm}(\mathrm{s})$ and $142.03 \mathrm{ppm}$ (s). The data obtained was compared with diterpenoids previously described in the literature ${ }^{16}$.

For compound 7 , the signal at $\delta=1.58 \mathrm{ppm}(\mathrm{s}, 3 \mathrm{H})$ corresponding to carbon-16 hydrogens were observed in the ${ }^{1} \mathrm{H}-\mathrm{NMR}$ spectrum, and the signals at $\delta=5.42 \mathrm{ppm}(\mathrm{d}, J=8.3 \mathrm{~Hz}, 1 \mathrm{H})$ and $\delta=3.73 \mathrm{ppm}(\mathrm{dd}, J=5.8$ and $11.4 \mathrm{~Hz}$, $1 \mathrm{H})$ were assigned to the vinyl hydrogen and to carbon-7 hydrogen geminal to the hydroxyl group, respectively. While, in the ${ }^{13} \mathrm{C}-\mathrm{NMR}$ spectrum, the four carbons that are part of the double bonds were observed at $\delta=121.73 \mathrm{ppm}(\mathrm{d})$, $132.73 \mathrm{ppm}(\mathrm{s}), 136.30 \mathrm{ppm}(\mathrm{s})$ and $141,84 \mathrm{ppm}(\mathrm{s})$, while the carbon bound to the hydroxyl group was observed at $\delta=69.16 \mathrm{ppm}$ (d).

Through ${ }^{13} \mathrm{C}$-NMR spectroscopy, it was determined that product 8 had a double bond with the signals displaced at $\delta=132.62 \mathrm{ppm}(\mathrm{s})$ and 144.28 
ppm (s), and a carbon attached to a hydroxyl group at $\delta=70.97 \mathrm{ppm}$ (s). In the ${ }^{1} \mathrm{H}-\mathrm{NMR}$ spectrum, the signal of the carbon-7 hydrogen germinal to the acetate group at $\delta=4.79 \mathrm{ppm}(\mathrm{dd}, J=6.3$ and $11.5 \mathrm{~Hz})$ and the signal of the carbon-16 hydrogen geminal to hydroxyl group at $\delta=1.17 \mathrm{ppm}(\mathrm{s}, 3 \mathrm{H}, \mathrm{H}-16)$ were observed.

To determine the stereochemistry of carbon-13 of compound 8 , NOESY spectroscopy was performed, where no interactions were observed between the carbon-16 hydrogens and the carbon-17 hydrogens, or those of the acetate group, which have a $\beta$-orientation described. However, interactions between the carbon-16 hydrogens and other hydrogens of the structure, which have not been assigned by the overlap, were actually observed. Nevertheless, those were not coupled with substituents in $\beta$ orientation.

\section{Antibacterial activity}

The results of the antibacterial tests that were performed with the natural diterpenoids 1 and 2, and semisynthetic 3-8, are shown in Figure 2. The graphs show that the natural diterpenoids isolated from $A$. compact have no biological activity against none of the tested bacteria, since no inhibition zone was observed around the paper discs. However, semisynthetic diterpenoids 3 , 5 and 8 showed antibacterial activity against three bacteria used, observing the inhibition zones between 7 and $9 \mathrm{~mm}$. For compounds 6 and 7 activity was observed only against two bacteria, although in the case of compound 6 against $S$. aureus the inhibition zone was less than $6.5 \mathrm{~mm}$, which is very close to the diameter of the paper disc. Finally, compound 4 was only active against $S$. aureus with an inhibition zone of $6.7 \mathrm{~mm}$

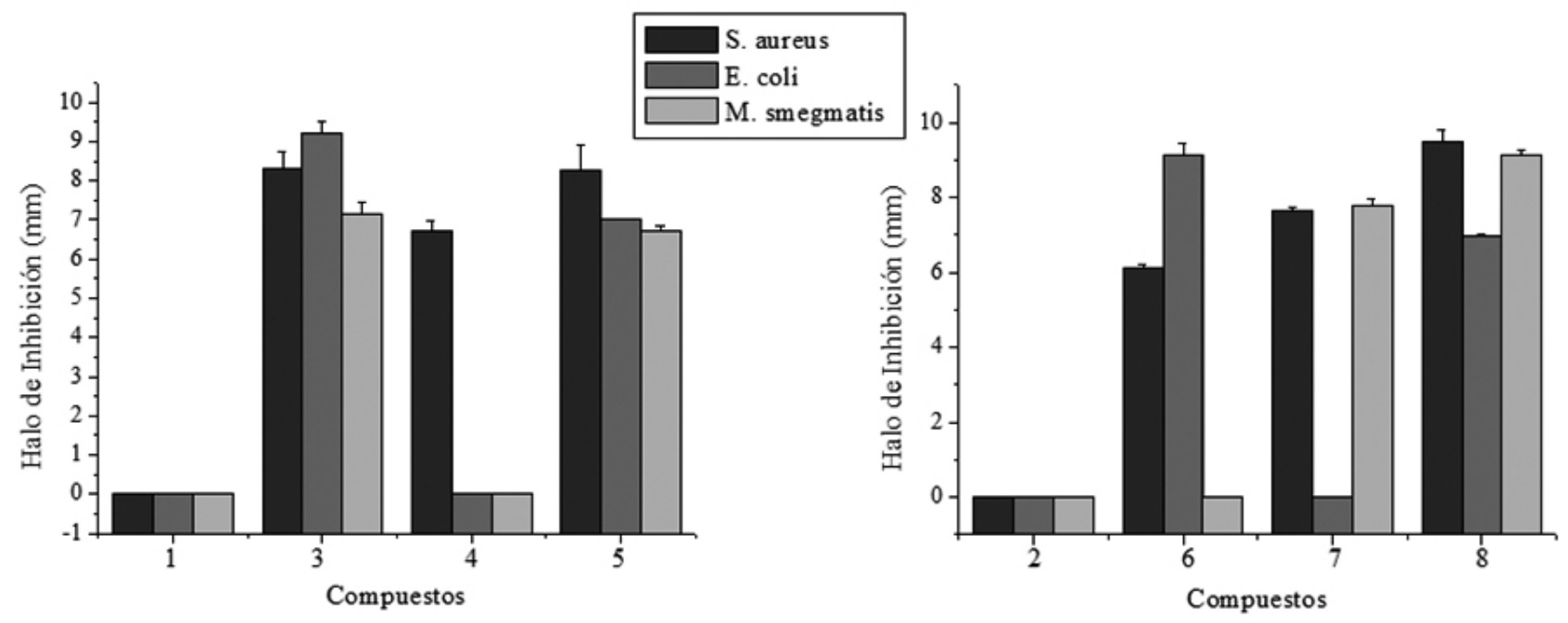

Figure 2. Antibacterial activity of natural and semi-synthetic diterpenoids from A. compact. The graph on the left shows the results for mulinolic acid (1) and its derivatives. The graph on the right shows the results for azorellanol (2) and its derivatives.

All the results obtained were compared with the positive control ampicillin $(1 \mathrm{mg} / \mathrm{mL})$ whose inhibition zones were $33.3 \mathrm{~mm}$ for $S$. aureus, $27.3 \mathrm{~mm}$ for E. coli and $12.7 \mathrm{~mm}$ for M. smegmatis.

\section{MIC determination}

In order to determine the minimum inhibitory concentration, two of the compounds that showed a better activity against the three bacteria tested were used. MIC determination was carried out by disc diffusion assay and the compounds tested were the semisynthetic acid 12-oxo-11,13- $\alpha$, $\alpha$-dihydroximulin-20-oico (3) and 7-acetoxy-12,13-dihydroximulin-9-ene (8), and the results are observed in Table 1.

Table 1. MIC results for compounds 3 and $\mathbf{8}$.

\begin{tabular}{|c|c|c|c|}
\hline Compound & S. aureus & E. Coli & M. smegmatis \\
\hline $\mathbf{3}$ & $200 \mu \mathrm{g}$ & $300 \mu \mathrm{g}$ & $200 \mu \mathrm{g}$ \\
\hline $\mathbf{8}$ & $100 \mu \mathrm{g}$ & $200 \mu \mathrm{g}$ & $200 \mu \mathrm{g}$ \\
\hline
\end{tabular}

\section{DISCUSSION}

Mulinolic acid and azorellanol were isolated as abundant diterpenoids from the $n$-hexane extracts of $A$. compacta. The semisynthetic compounds reported in this article: 12-oxo-11,13- $\alpha, \alpha$-dihydroximulin-20-oico acid (3), 11-oxo-12,13- $\alpha, \alpha$-dihydroximulin-20-oic acid (4), 11,12-dioxo-13- $\alpha$ hydroxymulin-20-oic acid (5) and 7-acetoxy-12,13-dihydroxymulin-9-ene (8), have not previously been described as diterpenoids derivatives of $A$ compact.

The ability of diterpenoids to inhibit the bacterial growth was determined in vitro by disc diffusion assay using three known bacteria: Staphylococcus aureus, Escherichia coli and Mycobacterium smegmatis. This method allowed the simultaneous comparison of the results expressed in inhibition zones of both natural diterpenoids and their derivatives, in a single culture, reducing the possibilities of error when performed in separate broth cultures or the effect of external agents such as the solvent used for the dilution of the samples.
The results indicated that natural diterpenoids showed no antibacterial activity, while their derivatives improved this characteristic. Compound 3, derived from mulinolic acid (1), showed the best activity among the three derivatives, possibly associated to the increase of polar functional groups and the distribution of these in the structure, since the hydroxyl groups being more separated keeping the ketone between them respect to the compound 4 , generates a rearrangement and distribution of polarity that could favor the mechanism of antibacterial action.

In the case of azorellanol (2), the most active derivative against $S$. aureus and $M$. smegmatis was compound 8 , which does not present a greater number of polar functional groups, but its structure lacks of cyclopropane group that provides rigidity to the azorellane skeleton. This is also reflected in compound 6, which does not have hydroxyl groups in its structure, but was the most active against $E$. coli.

The results of the MIC determination showed that the most active compounds against the bacteria tested inhibit the bacterial growth to a concentration over $100 \mu \mathrm{g}$. Only two compounds were tested because they had a better biological activity compared to the rest of the semi-synthetic diterpenoids and the general results of inhibition of bacterial growth are not significant in comparison with the reference antibiotic.

\section{CONCLUSIONS}

The derivatives of natural diterpenoids from $A$. compact showed an increase in biological activity respect to their predecessors mulinolic acid and azorellanol, therefore it is possible to modify the biological activity of diterpenoids considered inert by simple modification of their structures. Compounds 3, 6 and 8 showed a better increase in antibacterial activity against the three organisms tested. However, the results presented are not comparable with those obtained by the ampicillin as positive control, since the calculated inhibition zones are insignificant respect to those obtained by the antibiotic. 


\section{ACKNOWLEDGMENTS}

The research reported in this article was funded by the Fondecyt project No. 1120199 and was carried out in the Marine Natural Products Laboratory of the Faculty of Sciences of the Universidad de Chile. Solange Núñez thanks CONICYT for the national doctorate scholarship $\mathrm{N}^{\circ} 21130787$.

\section{REFERENCES}

1. Castro V, Villagrán C. Ciencia indígena de los Andes del norte de Chile, Universitaria, Santiago, 2004.

2. Melcher E. El norte de chile: su gente, desiertos y volcanes, Universitaria, Santiago, 2004

3. Belov M. Azorella compacta. [accessed 25 May 2016]

4. http://www.chileflora.com/Florachilena/FloraSpanish/HighResPages/ SH2013.htm (2013)

6. C. Kleier, P. Rundel, Austral Ecol 29, 461, (2004)

7. Y. Gebhardt, G. Forkmann, R. Lukacin, S. Martens, U. Matern, S. Witte, Phytochemistry 66, 1273, (2005).

8. K. Brandt, L. Christensen, J. Pharm. Biomed. Anal. 41, 683, (2006).

9. M. Budêsínsky, M. Holub, Phytochemistry 25, 2015, (1986).

10. J. Cherng, W. Chiang, L. Chiang, Food Chem. 106, 944, (2008).

11. S. Razavi, G. Zarrini, Russ. J. Bioor. Chem. 36, 359, (2010).

12. E. Ellmerer, M. Ganzera, R. Greil, K. Jöhrer, J. Mader, B. Schubert, E. Sigmund, H. Stuppner, C. Zidorn, J. Agric. Food Chem. 53, 2518, (2005)

13. J. Harrorne, C. Williams, Phytochemistry 11, 1741, (1972).
14. F. Abolhasani, B. Nickavar, Pak. J. Pharm. Sci. 22, 30, (2009).

15. G. Arias, E. Stashenko, R. Torres, Scientia Et Technica año XIII, 75 (2007).

16. A. Netrusov, I. Parshikov, J. Sutherland, Biotechnol. Adv. 30, 1516, (2012).

17. A. Ardiles, G. Molina-Salinas, J. Bórquez, I. González-Collado, L. Loyola, S. Said-Fernández, A. San-Martín, L. Peña-Rodríguez, Fitoterapia 81, 50 , (2010).

18. A. Ardiles, P. Becerril-Montes, J. Bórquez, F. Escalante-Erosa, I. GonzálezCollado, L. Loyola, G. Molina-Salinas, S. Said-Fernández, A. San Martín, L. Peña-Rodríguez, A.Yam-Puc, Phytochem. Rev. 9, 271, (2010).

19. I. Neira, L. Poblete, P. Porcille, P. Silva, J. Araya, J. Bórquez, G. Morales, L. Loyola, H. Sagua, Bol. Chil. Parasitol. 53, 9, (1998).

20. J. Bórquez, N. Fuentes, L. Loyola, G. Morales, H. Sagua, A. San Martín, J. Soto, Phytother. Res. 19, 713, (2005).

21. N. Backhouse, J. Bórquez, C. Delporte, L. Loyola, P. Salinas, A. SanMartín, Bioorg. Med. Chem. Lett. 11, 1187, (2003).

22. P. Becerril-Montes, J. Bórquez, F. Escalante-Erosa, L. Loyola, G. MolinaSalinas, L. Peña-Rodríguez, S. Said-Fernández, A. Yam-Puc, Fitoterapia $81,219,(2010)$

23. J. Benites, P. Díaz, J. López, J. Ordóñez, E. Pastene, M. Rojas, L. Rojo, B Latinoam. Caribe Pl. 8, 498, (2009).

24. C. Areche, C. Campos-Briones, C. Lima, E. Pérez, F. Rojas-Alvarez, B Sepúlveda, J. Pharm. Pharmacol. 65, 1231, (2013).

25. J. Bórquez, L. Loyola, V. Manriquez, G. Morales, A. San-Martin, O. Wittke, Tetrahedron 54, 15533, (1998).

26. A. Loyola, J. Bórquez, G. Morales, A. San-Martin, Phytochemistry 43 165, (1996). 